Sains Malaysiana 50(1)(2021): 85-92

http://dx.doi.org/10.17576/jsm-2021-5001-09

\title{
Physicochemical Characterization of Jatropha podagrica Seed Oil for Potential Biodiesel Production and other Industrial Applications in Thailand
}

(Pencirian Fisikokimia Minyak Biji Jatropha podagrica bagi Pengeluaran Biodisel Berpotensi dan Aplikasi Industri lain di Thailand)

\author{
Duangporn Premjet, Abraham Kusi Obeng, Hah Young Yoo, Seung Wook Kim \& Siripong Premjet*
}

\section{ABSTRACT}

Jatropha is considered as one of the most promising potential oil sources for biodiesel production and other industrial applications. However, research on the potential of Jatropha seed oil is mainly focused on Jatropha curcas, with other species receiving little attention. The physicochemical properties of J. podagrica seed oil was studied to determine its potential as feedstock for biodiesel production and other industrial applications in Thailand. The seed oil was extracted with n-hexane from milled kernels using the soxhlet extractor and subsequently characterised for free fatty acids, iodine value, viscosity, saponification value, density, and acid value. The fatty acid profile of the seed oil was also analysed using gas chromatography (GC). Analysis of the physical properties of the J. podagrica seed kernel showed lower average physical characteristics when compared to those of J. curcas seed kernel. J. podagrica seeds had high oil content comparable to J. curcas oil content. The main fatty acid components of the seed oil were oleic acid (15\%) and linoleic acid (70\%). Generally, the results of the physicochemical analysis indicated that J. podagrica seed oil would be very useful for the production of soap and shampoo in Thailand. To produce biodiesel from the seed oil, a two-step acid-catalysed transesterification process would be appropriate.

Keywords: Biodiesel; Jatropha curcas; Jatropha podagrica; methyl esters; non-edible oil

\section{ABSTRAK}

Jatropha dianggap sebagai salah satu sumber minyak yang sangat berpotensi untuk pengeluaran biodiesel dan aplikasi industri lain. Walau bagaimanapun, penyelidikan mengenai potensi minyak biji Jatropha hanya difokuskan ke atas Jatropha curcas manakala spesies lain kurang mendapat perhatian. Sifat fizikokimia minyak biji J. podagrica telah dikaji untuk menentukan potensinya sebagai bahan untuk pengeluaran biodiesel dan aplikasi industri lain di Thailand. Minyak biji telah diekstrak dengan n-heksana daripada isirong yang telah digiling menggunakan pengekstrak soxhlet dan kemudiannya dicirikan untuk asid lemak bebas, nilai iodin, kelikatan, nilai saponifikasi, ketumpatan dan nilai asid. Profil asid lemak minyak biji juga dianalisis menggunakan kromatografi gas (GC). Analisis sifat fizikal isirong biji J. podagrica menunjukkan purata ciri fizikal yang lebih rendah jika dibandingkan dengan isirong biji J. curcas. Biji J. podagrica mempunyai kandungan minyak yang tinggi standing dengan kandungan minyak J. curcas. Komponen utama asid lemak bagi minyak biji adalah asid oleik (15\%) dan asid linoleik (70\%). Secara umumnya, hasil analisis fizikokimia menunjukkan bahawa minyak biji J. podagrica akan sangat berguna untuk pengeluaran sabun dan syampu di Thailand. Untuk menghasilkan biodiesel daripada minyak biji, proses transesterifikasi pemangkin asid dua langkah adalah bersesuaian.

Kata kunci: Biodiesel; Jatropha curcas; Jatropha podagrica; metil ester; minyak yang tidak boleh dimakan

\section{INTRODUCTION}

The genus Jatropha, belonging to the Euphorbiaceae family, consists of over 70 species of shrubs including $J$. curcas, J. pohliana, J. podagrica, and J. gossypiifolia (de Oliveira et al. 2009). These species are native to Central America, but are now growing in different tropical and subtropical areas of the world (Adebayo \& Ameen 2017). The plant grows rapidly and can withstand drought, pest, and diseases (Wu et al. 2012). It can also survive on marginal lands under a wide range of climatic conditions (Atabani et al. 2013). Cultivation of the plant requires simple technology and is not capital intensive (Pandey et al. 2012). 
The Jatropha plant has many attributes, uses, and significant potentials. The seeds and other parts of the plant have traditionally been used for the production of oil, soap, and medicinal compounds. The stem has been used for the treatment of gum inflammation, toothache, gum bleeding, and sexually transmitted diseases. The leaves and latex have also been reported as very effective in the treatment of cuts, bruises, mouth, and throat sores (Pandey et al. 2012). Jatropha seed oil is a very important raw material for the production of broad industrial products. It can be used to produce cosmetics, soap, paraffin, and candles. Currently, Jatropha is considered as one of the most promising potential oil sources for the production of biodiesel worldwide (Borugadda \& Goud 2012).

Non-edible oil from $J$. curcas seed has attracted great attention globally as a promising alternative oil source for biodiesel production and other industrial applications (Khan et al. 2014). Several researches have reported that biodiesel from $J$. curcas oil shares similar properties with petroleum-based diesel (Chouhan \& Sarma 2013; Jaliliannosrati et al. 2013; Lim \& Lee 2013; Raia et al. 2017). J. curcas biodiesel has distinct fuel properties that make it an alternative to petrol diesel. Quality fuel indicators such as the cetane index, viscosity, flash point, calorific value, sulfur content, and pour point of $J$. curcas biodiesel meet the ASTM standards (Thapa et al. 2018). However, research on the potential of seed oil from other Jatropha species is very limited. Another common species of great importance in the genus Jatropha in Thailand is J. podagrica (Rumzhum et al. 2012). It can adapt to different environmental and soil conditions without the need for extra economic inputs. J. podagrica seed oil could be used as raw material for biodiesel production and other industrial applications in Thailand (Tsegay et al. 2017). However, the potential of seed oil from $J$. podagrica has not been exploited. $J$. podagrica seed oil was therefore assessed as potential feedstock for biodiesel production and other industrial applications in this study.

\section{Materials AND Methods}

\section{PREPARATION OF J. PODAGRICA SEEDS}

Fresh, healthy, and whole seeds of $J$. podagrica (Figure 1) were collected from Lablae, Uttaradit Province, Thailand (17³9'44"N, $100^{\circ} 1 ' 57^{\prime}$ 'E, 91 m altitude). Seed collection was carried out from July to September 2014. The coats of the seeds were removed and the physical characteristics of the kernel including length, width and weight were then recorded. The seed kernels were then dried in a hot air oven at $60{ }^{\circ} \mathrm{C}$ for $12 \mathrm{~h}$. The dried seeds were then milled using the SM 100, Rtsch, Rheinis-che StraBe 36-D-42781 (Haan, North Rhine-Westphalia, Germany) miller and used for oil extraction.

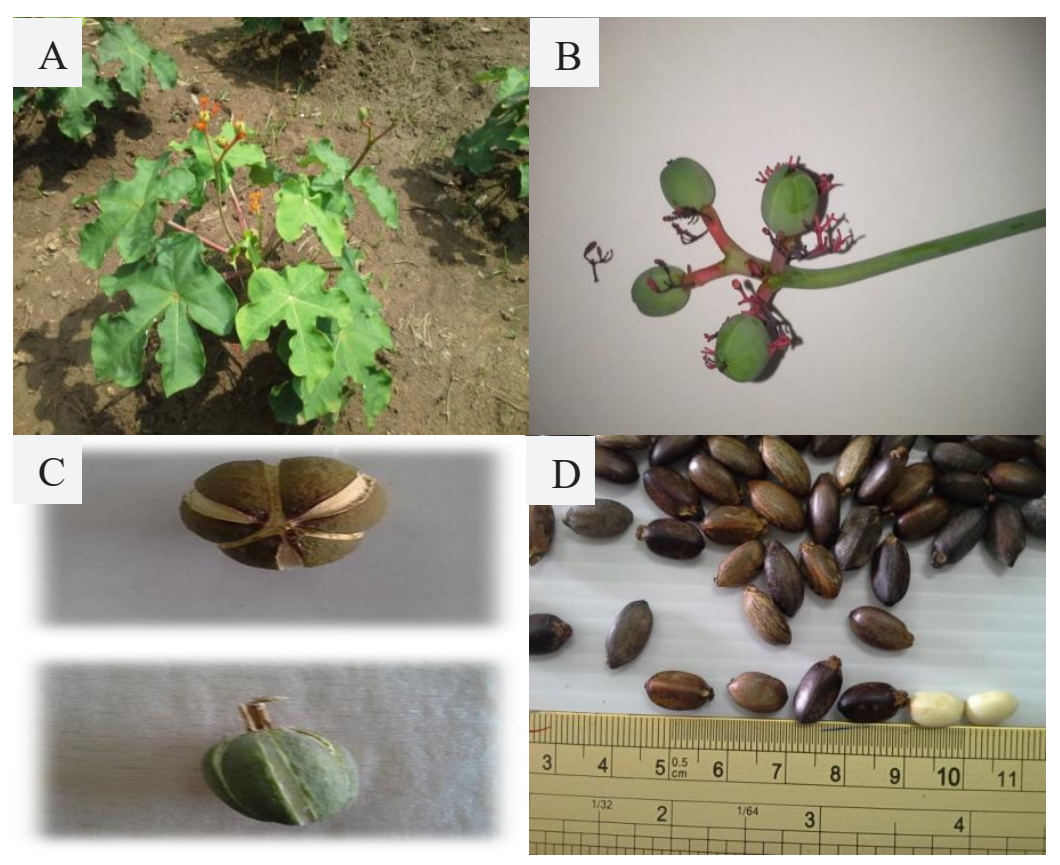

FIGURE 1. Photograph of (A) young J. podagrica plant on the field, (B) fresh fruits, (C) dry fruits and (D) seeds 


\section{OIL EXTRACTION}

$J$. podagrica seed oil was extracted from the milled kernels (15 g dry weight) with n-hexane (200 mL) using the soxhlet extractor at $60{ }^{\circ} \mathrm{C}$ for $24 \mathrm{~h}$ by following the in-house method TE-CH-208 from the Association of Official Analytical Chemists (AOAC 2012). To remove the moisture, the micelle produced was dried over anhydrous $\mathrm{MgSO}_{4}$ and filtered. The solvent was then removed using rotary evaporator at $45{ }^{\circ} \mathrm{C}$. The oil was collected in a vial and kept in a desiccator till a constant weight was attained. The volume of oil obtained was then measured. The oil content was expressed as the percentage of oil in the dry matter of milled kernel.

\section{FATTY ACID METHYL ESTERS ANALYSIS}

The fatty acid composition of the seed oil was determined using the in-house method TE-CH-208 based on AOAC (2012). Pyrogallic acid was added to $J$. podagrica oil $(0.2 \mathrm{~g})$ to prevent oxidation of the oil. To analyse fatty acid composition, $0.1 \mathrm{~mL}$ oil was derivatized to fatty acid methyl esters (FAMEs) using $1 \mathrm{~mL}$ of $10 \%$ (w/w) boron trifluoride-methanol (BF3-methanol) before being injected into the gas chromatography (GC, Agilent $6890 \mathrm{~N}$, Agilent Technologies Inc., CA, USA). The GC was equipped with Agilent HP-FFAP capillary column, $25 \mathrm{~m}-0.25 \mathrm{~mm}$ ID, $0.22 \mu \mathrm{m}$ film thickness. Triundecanoin (C11:O) was used as internal standard with helium as carrier gas at an inlet pressure of 120 psi. The temperature of the injection port and detector (FID) was programmed at 200 to $240{ }^{\circ} \mathrm{C}$. The column was operated at the flow rate of $0.8 \mathrm{~mL} \mathrm{~min}^{-1}$ and the temperature was initially set at $170{ }^{\circ} \mathrm{C}$ for $4 \mathrm{~min}$, then adjusted to $180{ }^{\circ} \mathrm{C}$ and finally to $190{ }^{\circ} \mathrm{C}$. The injection volume was $1 \mu \mathrm{L}$. Identification of FAME peak was achieved by comparing the retention times with those of authentic standards analysed under the same conditions.

\section{CHARACTERISATION OF $J$. podagrica SEED OIL}

The physicochemical properties of the extracted seed oil were analysed using standard methods from the AOAC (2012). The properties analysed included free fatty acid (FFA), density, viscosity, acid value, iodine, and saponification values.

\section{PROXIMATE ANALYSIS}

Proximate analyses of seed kernels, de-oiled seed cake and seed capsules including moisture content, ash, crude fibre, crude protein, oil content, and energy were carried out as described by AOAC (2006). The carbohydrate content was calculated from the other components.

\section{STATISTICAL ANALYSIS}

The data collected on proximate analysis were subjected to one-way analysis of variance (ANOVA) using SPSS version 16.0 (SPSS Inc., Chicago, IL, USA). Treatment means were compared by Tukey's test at 5\% significance level. The analyses were performed in triplicate and the average values with their standard deviations were presented.

\section{RESULTS AND DISCUSSION}

PHYSICAL CHARACTERISTICS OF J. podagrica SEEDS

$J$. podagrica seed is the main organ for storing oil in the plant. Similar to J. curcus, the physical characteristics of the seed, among other factors, have significant influence on the oil yield (Wu et al. 2012). The average weight of $100 \mathrm{~J}$. podagrica seed kernels were found to be $15.52 \pm 0.19 \mathrm{~g}$, corresponding to an average seed kernel weight of $0.16 \mathrm{~g}$. On the other hand, seed kernel in the current study had an average length and width of $12.11 \pm 0.71$ and $6.03 \pm 0.41 \mathrm{~mm}$, respectively. The average physical characteristics of $J$. podagrica seed kernel in this study were lower than those reported for J. curcas seed kernel (Abou-Arab \& Abu-Salem 2010; Wu et al. 2012).

\section{J. podagrica SEED OIL}

The oil yield of $J$. podagrica seed kernel was affected by the season in which the seeds were harvested. Seeds harvested during the dry season contained higher $(\mathrm{p}<0.05)$ oil yield $(31 \%)$ when compared those harvested in the rainy season $(24 \%)$ (Table 1$)$. The high oil yield makes seeds harvested in the dry season very ideal for biodiesel production and other industrial applications. The yield of oil extracted from J.podagrica seed kernel in the current study was comparable to those reported for $J$. curcas seeds by several researchers which were $27 \%$ (Abou-Arab \& Abu-Salem 2010), 32\% (de Oliveira et al. 2009), 32\% (Kibazohi \& Sangwan 2011), 34\% (Evon et al. 2013), 43\% (seed biomass size $\leq 0.5 \mathrm{~mm}$ ), 32\% (seed biomass size $\geq 0.5$ but $\leq 1.1 \mathrm{~mm}$ ) (Jaliliannosrati et al. 2013) and 47\% (Akintayo 2004). However, the oil yield in this study was higher when compared to that of several promising non-edible oilseed crops for biodiesel production such as Raphanus sativus L. at 26\% (Shah et al. 2013), Sapium sebiferum L. at 25\% (Wang et al. 2011), rubber seed at 24\% (Roschat et al. 2017), Aleurites moluccana at $20 \%$, Moringa oleifera at $25 \%$, and Pachira glabra at 23\% (Kibazohi \& Sangwan 2011). 
TABLE 1. Proximate composition of J. podagrica seed kernel, cake and capsule

\begin{tabular}{|c|c|c|c|c|}
\hline \multirow{2}{*}{ Composition (\%) } & \multicolumn{2}{|c|}{ Seed kernel } & \multirow{2}{*}{$\begin{array}{c}\text { De-oiled seed } \\
\text { kernel }\end{array}$} & \multirow[t]{2}{*}{ Seed capsule } \\
\hline & Dry season & Rainy season & & \\
\hline Moisture & $3.51 \pm 0.41^{\mathrm{c}}$ & $5.61 \pm 0.52^{\mathrm{b}}$ & $2.13 \pm 0.36^{\mathrm{d}}$ & $13.00 \pm 0.29^{\mathrm{a}}$ \\
\hline Ash & $7.74 \pm 0.63^{\mathrm{a}}$ & $7.58 \pm 0.40^{\mathrm{a}}$ & $6.97 \pm 0.37^{\mathrm{b}}$ & $4.20 \pm 0.33^{c}$ \\
\hline Oil & $30.87 \pm 0.88^{a}$ & $24.09 \pm 0.75^{\mathrm{b}}$ & $2.19 \pm 0.47^{\mathrm{d}}$ & $5.38 \pm 0.19^{c}$ \\
\hline Protein & $28.74 \pm 0.69^{a}$ & $22.42 \pm 0.56^{\mathrm{c}}$ & $27.65 \pm 0.51^{b}$ & $2.00 \pm 0.25^{\mathrm{d}}$ \\
\hline Fibre & $7.45 \pm 0.21^{\mathrm{c}}$ & $10.54 \pm 40^{\mathrm{b}}$ & $7.13 \pm 0.21^{\mathrm{c}}$ & $66.38 \pm 0.39^{a}$ \\
\hline Carbohydrates & $21.69 \pm 0.52^{\mathrm{b}}$ & $29.76 \pm 0.49^{\mathrm{a}}$ & $21.69 \pm 0.52^{\mathrm{b}}$ & $9.04 \pm 0.23^{\mathrm{c}}$ \\
\hline Energy (cal g-1) & - & - & - & 3632 \\
\hline
\end{tabular}

Data are presented as mean $\pm \mathrm{SD}$. Means in the same row with similar superscript $\left({ }^{\mathrm{a}, \mathrm{b}, \mathrm{c}, \mathrm{d}}\right)$ did not significantly differ $(\mathrm{p}>0.05)$

\section{FATTY ACID COMPOSITION}

The main components of $J$. podagrica seed oil were the unsaturated fatty acids, linoleic acid (70\%), and oleic acid (15\%). Saturated fatty acids, primarily stearic acid $(6 \%)$, and palmitic acid (9\%), were also identified (Figure $2 \&$ Table 2). Supamathanon et al. (2011) reported that the components of $J$. curcas seed oil cultivated in the North-Eastern part of Thailand were linoleic acid and oleic acid. In addition, stearic acid and palmitic acid were the major saturated fatty acids reported. Emil et al.
(2010) also reported the unsaturated fatty acids, linoleic acid, and oleic acid, as well as the saturated fatty acids, stearic acid, and palmitic acid, as the major fatty acid components of $J$. curcas seed oil from Thailand. The fatty acid components of $J$. podagrica seed oil in this study were comparable to those of oils from J. curcas seed, soybean and sunflower (Table 2). However, the linoleic acid content was very high while the oleic acid content was lower in $J$. podagrica when compared to those in $J$. curcas and soybean.

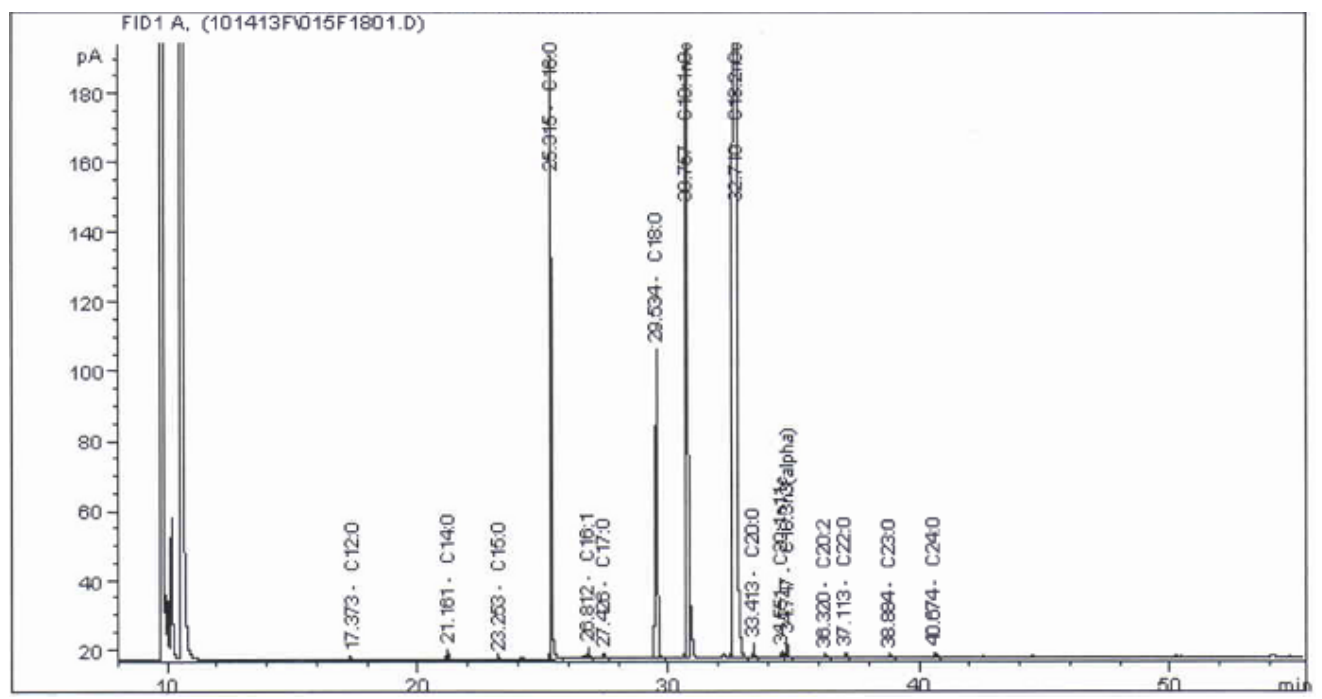

FIGURE 2. Fatty acid composition of J. podagrica FAMEs detected by GC 
TABLE 2. Fatty acid composition of J. podagrica seed oil

\begin{tabular}{lcccc}
\hline \multicolumn{1}{c}{ Fatty acid composition (\%) } & $\begin{array}{c}\text { J. podagrica } \\
\text { (Present study) }\end{array}$ & $\begin{array}{c}\text { J. curcas } \\
\text { (Emil et al. 2010) }\end{array}$ & $\begin{array}{c}\text { Soybean } \\
\text { (Karmakar et al. 2010) }\end{array}$ \\
\hline Lauric acid (C12:0) & 0.02 & - & - & - \\
Myristic acid (C14:0) & 0.13 & 0.10 & $<0.50$ & $<1.00$ \\
Pentadecanoic acid (C15:0) & 0.01 & - & - & - \\
Palmitic acid (C16:0) & 8.51 & 13.20 & $7.00-11.00$ & $3.00-6.00$ \\
Heptadeconoic acid (C17:0) & 0.09 & 0.10 & - & - \\
Stearic acid (C18:0) & 5.57 & 7.70 & $2.00-6.00$ & $1.00-3.00$ \\
Arachidic acid (C20:0) & 0.18 & 0.30 & $<1.00$ & $0.60-4.00$ \\
Behenic acid (C22:0) & 0.04 & - & - & 0.80 \\
Tricosanoic acid (C23:0) & 0.02 & - & - & - \\
Lignoceric acid (C24:0) & 0.05 & - & - & - \\
Saturated fat & 14.62 & - & - & - \\
Palmitoleic acid (C16:1) & 0.16 & 0.60 & $19.00-34.00$ & $14.00-35.00$ \\
Oleic acid (18:1) & 14.71 & 48.80 & - & - \\
Eicosenoic acid (C20:1) & 0.09 & - & - & - \\
Monounsaturated fatty acid & 14.97 & - & - & - \\
Linoleic acid (C18:2) & 70.15 & 28.80 & $43.00-56.00$ & $44.00-75.00$ \\
$\alpha$-Linolenic acid (C18:3) & 0.24 & 0.10 & $5.00-11.00$ & $<1.5$ \\
Eicosadienoic acid (C20:2) & 0.02 & - & - & - \\
Polyunsaturated fatty acid & 70.41 & - & - & - \\
Unsaturated fat & 85.38 & & - & - \\
\hline
\end{tabular}

$J$. podagrica seed oil was found to be liquid at room temperature and showed a yellow to soft brown color. The chemical properties of the seed oil (Table 3) showed an

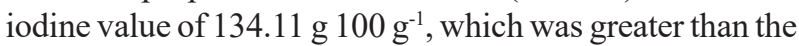

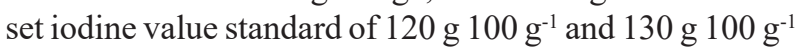
recommended for biodiesel production by Europe's EN 14214 and EN 14213 specifications, respectively (Saluja et al. 2016), but less than that of the Spanish regional standards (140 g $\left.100 \mathrm{~g}^{-1}\right)$ (Chuah et al. 2016). The iodine value in this study was also higher than that reported for $J$. curcas seed oil (Table 3), but lower when compared to those that have been reported for several non-edible seed oils studied for biodiesel production including Cucurbita pepo (150.37 g $\left.100 \mathrm{~g} \mathrm{~g}^{-1}\right)$ and Cucumis melo (135.36 $100 \mathrm{~g} \mathrm{~g}^{-1}$ ) (Ibeto et al. 2012). However, the value was within the range reported for popular edible oils, soybean, and sunflower, which have been used in first generation biodiesel production (Table 3 ). The high linoleic acid content (Table 2) in this study may have contributed to the high iodine value. Iodine value indicates the level of unsaturation in the oil (Emil et al. 2010). A high iodine value is associated with the production of several degradation products, due to low oxidation. This leads to the formation of deposits on the piston ring grooves, piston rings, and nozzles of diesel engines, affecting their smooth running (Pinzi et al. 2009). Different countries have established various iodine value limits around the EU EN 14214 specifications.

The saponification value $\left(186.70 \mathrm{mg} \mathrm{KOH} \mathrm{g}^{-1}\right)$, free fatty acids $(0.91 \%)$, and viscosity $\left(36.47 \mathrm{cP}, 40^{\circ} \mathrm{C}\right)$ of $J$. podagrica seed oil in the current study were lower when compared to those reported for J. curcas seed oil. On the other hand, unlike the saponification value, the free fatty acids and viscosity of $J$. podagrica seed oil 
was higher when compared to those of soybean and sunflower oils (Table 3 ). The saponification value is very significant in checking oil adulteration. Despite the lower saponification value in this study when compared to $J$. curcas, soybean, and sunflower, it was still very high. This makes $J$. podagrica seed oil more suitable for liquid soap and shampoo production. For the production of biodiesel from $J$. podagrica seed oil, alkaline-catalysed transesterification may not be suitable due to an increase in soap formation and possible increase in viscosity as a result of the high saponification value (Abbaszaadeh et al. 2012). However, acid-catalysed transesterification has been recommended for oils with high FFA or the conversion of soaps to esters, although the process is slow. Optimisation of the catalyst loading, alcohol to oil molar ratio, process temperature and time may help to enhance the efficiency of conversion during acid-catalysed transesterification (Borugadda \& Goud 2012). To increase the yields of methyl esters, a two-step transesterification process may efficiently convert the oil to biodiesel (Ibeto et al. 2012). The viscosity of the oil is a very important factor to determine its suitability for biodiesel production. It affects the efficiency of injection as well as combustion. High viscosity results in high pressure and injection volume due to an increase in the pulling force in the injection pump (Pinzi et al. 2009). The low viscosity of J. podagrica seed oil gave it better lubrication properties when compared to that of J. curcas (Table 3). However, it was too high to be used directly as fuel for engines. Transesterification of the oil may help to reduce its viscosity and enhance its use as biodiesel for engines.

The density of $J$. podagrica seed oil $\left(0.90 \mathrm{~g} \mathrm{~cm}^{-3}\right)$ was found to be similar to those of $J$. curcas, soybean and sunflower (Table 3). Nevertheless, the acid value of $J$. podagrica seed oil $\left(127.45 \mathrm{mg} \mathrm{KOH} \mathrm{g}^{-1}\right)$ was very high when compared to those of $J$. curcas, soybean, sunflower (Table 3) and other vegetable oil studied for biodiesel production including Brachystegia eurycoma (27.08 mg KOH g${ }^{-1}$ ), Cucurbita pepo (36.47 mg KOH $\left.\mathrm{g}^{-1}\right)$, Luffa cylidrica $\left(2.47 \mathrm{mg} \mathrm{KOH} \mathrm{g}^{-1}\right)$, Cucumis melo (5.40 $\mathrm{mg} \mathrm{KOH} \mathrm{g}^{-1}$ ), and Arachis hypogea $(2.61 \mathrm{mg} \mathrm{KOH}$ $\mathrm{g}^{-1}$ ) (Ibeto et al. 2012). The high acid value makes separation very difficult due to the formation of soap during transesterification. This results in low yield of biodiesel (Chuah et al. 2016). A sequence of acid catalysed processes is therefore ideal for biodiesel production from J. podagrica seed oil. Wang et al. (2011) reported a significant reduction in the acid value of $J$. curcas L., Euphorbia lathyris L., and Sapium sebiferum L. oils after application of a two-step catalytic process for biodiesel production.

TABLE 3. Chemical properties of J. podagrica seed oil

\begin{tabular}{|c|c|c|c|c|}
\hline Properties & $\begin{array}{l}\text { J. podagrica } \\
\text { (Present study) }\end{array}$ & $\begin{array}{c}\text { J. curcas } \\
\text { (Emil et al. 2010) }\end{array}$ & $\begin{array}{c}\text { Soybean } \\
\text { (Karmakar et al. 2010; }\end{array}$ & $\begin{array}{c}\text { Sunflower } \\
\text {; Verma \& Sharma 2016) }\end{array}$ \\
\hline Iodine number $\left({\left.\mathrm{g} 100 \mathrm{~g}^{-1}\right)}\right.$ & 134.11 & 92.53 & $128-143$ & $125-140$ \\
\hline Saponification value $\left(\mathrm{mg} \mathrm{KOH} \mathrm{g}^{-1}\right)$ & 186.70 & 216.09 & 195.30 & 193.14 \\
\hline Free fatty acids (FFA, \%) & 0.91 & 1.69 & 0.35 & - \\
\hline Viscosity $\left(\mathrm{cP}, 40^{\circ} \mathrm{C}\right)$ & 36.47 & 47.50 & 28.87 & 35.84 \\
\hline Density $\left(20^{\circ} \mathrm{C}, \mathrm{g} \mathrm{mL}^{-1}\right)$ & 0.90 & 0.90 & 0.91 & 0.92 \\
\hline Acid value (mg KOH g$\left.{ }^{-1}\right)$ & 127.45 & 42.78 & 0.71 & 0.50 \\
\hline Physical state at room temperature & Liquid & Liquid & - & - \\
\hline
\end{tabular}

\section{PROXIMATE ANALYSIS}

Analysis of the proximate composition of $J$. podagrica seed kernel, de-oiled seed kernel (seed cake) and seed capsule was shown in Table 1. The protein content (29\%) of seeds harvested in the dry season was also higher $(\mathrm{p}<0.05)$ than that of seeds harvested in the rainy season $(22 \%)$. The rainy season seeds recorded $6 \%$ moisture, $11 \%$ fibre and $30 \%$ carbohydrate contents which were higher $(\mathrm{p}<0.05)$ when compared to those of the dry season seeds $(4,7$, and $22 \%$, respectively). However, there was no difference $(\mathrm{p}>0.05)$ between the two groups of seeds in 
relation to their ash content (Table 1). The low moisture content of seeds harvested in the dry season further confirmed their suitability for biodiesel production and other industrial applications.

Oil extraction from $J$. podagrica seed kernel was accompanied by the production of large amount of seed cake. Analysis of the seed cake showed its good nutritional potential in the presence of high protein $(28 \%)$ and carbohydrate $(22 \%)$ contents (Table 1$)$. This established a good basis for more research into the potential of $J$. podagrica seed cake as feed resource and other industrial applications.

The main component of J. podagrica seed capsule was found to be fibre (Table 1). Minor components including oil, carbohydrates, and protein were also identified, an indication of the poor nutritional value of the capsule. On the other hand, the capsule may be a good source of fuel due to its energy content.

\section{CONCLUSION}

$J$. podagrica seed oil in this study was unsaturated due to its significant linoleic acid and oleic acid contents. The study showed that the seed oil is more suitable for the production of soap and shampoo in Thailand. To convert $J$. podagrica seed oil to biodiesel, acid-catalysed transesterification process is appropriate. A two-step transesterification to increase the yields of methyl esters would be better in the conversion process. The seed cake produced after oil extraction would be very useful as animal feed due to its high nutritional content. Nevertheless, more research is needed to determine if the seed cake is non-toxic.

\section{ACKNOWLEDGEMENTS}

This research was funded by the National Research Council of Thailand in the Fiscal year 2014-2015 (project number R2557B053).

\section{REFERENCES}

Abbaszaadeh, A., Ghobadian, B., Omidkhah, M.R. \& Najafi, G. 2012. Current biodiesel production technologies: A comparative review. Energy Conversion and Management 63(2012): 138-148.

Abou-Arab, A.A. \& Abu-Salem, F.M. 2010. Nutritional quality of Jatropha curcas seeds and effect of some physical and chemical treatments on their antinutritional factors. African Journal of Food Science 4(3): 93-103.

Adebayo, G. \& Ameen, O. 2017. Physico-chemical properties of biodiesel produced from Jatropha curcas oil and fossil diesel. Journal of Microbiology and Biotechnology Research 1(1): 12-16.

Akintayo, E.T. 2004. Characteristics and composition of Parkia biglobbossa and Jatropha curcas oils and cakes. Bioresource Technology 92(3): 307-310.
AOAC. 2012. Official Methods of Analysis of AOAC International. 19th ed. Maryland, USA: AOAC International. pp. 1-39.

AOAC. 2006. Official Methods of Analysis. 18th ed. Washington DC, USA: AOAC International. pp. 1-26.

Atabani, A.E., Mahlia, T.M.I., Badruddin, I.A., Masjuki, H.H., Chong, W.T. \& Lee, K.T. 2013. Investigation of physical and chemical properties of potential edible and non-edible feedstocks for biodiesel production, a comparative analysis. Renewable and Sustainable Energy Reviews 21(2013): 749-755.

Borugadda, V.B. \& Goud, V.V. 2012. Biodiesel production from renewable feedstocks: Status and opportunities. Renewable and Sustainable Energy Reviews 16(7): 4763-4784.

Chouhan, A.P.S. \& Sarma, A.K. 2013. Biodiesel production from Jatropha curcas L. oil using Lemna perpusilla Torrey ash as heterogeneous catalyst. Biomass and Bioenergy 55(2013): 386-389.

Chuah, L.F., Yusup, S., Aziz, A.R.A., Klemeš, J.J., Bokhari, A. \& Abdullah, M.Z. 2016. Influence of fatty acids content in non-edible oil for biodiesel properties. Clean Technologies and Environmental Policy 18(2): 473-482.

de Oliveira, J.S., Leite, P.M., de Souza, L.B., Mello, V.M., Silva, E.C., Rubim, J.C., Meneghetti, S.M.P. \& Suarez, P.A.Z. 2009. Characteristics and composition of Jatropha gossypiifolia and Jatropha curcas L. oils and application for biodiesel production. Biomass and Bioenergy 33(3): 449-453.

Emil, A., Yaakob, Z., Kumar, M.S., Jahim, J.M. \& Salimon, J. 2010. Comparative evaluation of physicochemical properties of Jatropha seed oil from Malaysia, Indonesia and Thailand. Journal of the American Oil Chemists Society 87(6): 689-695.

Evon, P., Kartika, I.A., Cerny, M. \& Rigal, L. 2013. Extraction of oil from Jatropha seeds using a twin-screw extruder: Feasibility study. Industrial Crops and Products 47(2013): 33-42.

Ibeto, C.N., Okoye, C.O.B. \& Ofoefule, A.U. 2012. Comparative study of the physicochemical characterization of some oils as potential feedstock for biodiesel production. ISRN Renewable Energy 2012: 1-5.

Jaliliannosrati, H., Amin, N.A.S., Talebian-Kiakalaieh, A. \& Noshadi, I. 2013. Microwave assisted biodiesel production from Jatropha curcas L. seed by two-step in situ process: Optimization using response surface methodology. Bioresource Technology 136(2013): 565-573.

Karmakar, A., Karmakar, S. \& Mukherjee, S. 2010. Properties of various plants and animals feedstocks for biodiesel production. Bioresource Technology 101(19): 7201-7210.

Khan, T.M.Y., Atabani, A.E., Badruddin, I.A., Badarudin, A., Khayoon, M.S. \& Triwahyono, S. 2014. Recent scenario and technologies to utilize non-edible oils for biodiesel production. Renewable and Sustainable Energy Reviews 37(2014): 840-851.

Kibazohi, O. \& Sangwan, R.S. 2011. Vegetable oil production potential from Jatropha curcas, Croton megalocarpus, Aleurites moluccana, Moringa oleifera, and Pachira glabra: Assessment of renewable energy resources for bio-energy production in Africa. Biomass and Bioenergy 35(3): 13521356. 
Lim, S. \& Lee, K.T. 2013. Process intensification for biodiesel production from Jatropha curcas L. seeds: Supercritical reactive extraction process parameters study. Applied Energy 103(2013): 712-720.

Pandey, V.C., Singh, K., Singh, J.S., Kumar, A., Singh, B. \& Singh, R.P. 2012. Jatropha curcas: A potential biofuel plant for sustainable environmental development. Renewable and Sustainable Energy Reviews 16(5): 2870-2883.

Pinzi, S., Garcia, I.L., Lopez-Gimenez, F.J., de Castro, M.D.L., Dorado, G. \& Dorado, M.P. 2009. The ideal vegetable oil-based biodiesel composition: A review of social, economical and technical implications. Energy and Fuels 23(5): 2325-2341.

Raia, R.Z., da Silva, L.S., Marcucci, S.M.P. \& Arroyo, P.A. 2017. Biodiesel production from Jatropha curcas L. oil by simultaneous esterification and transesterification using sulphated zirconia. Catalysis Today 289(2017): 105-114.

Roschat, W., Siritanon, T., Yoosuk, B., Sudyoadsuk, T. \& Promarak, V. 2017. Rubber seed oil as potential non-edible feedstock for biodiesel production using heterogeneous catalyst in Thailand. Renewable Energy 101(2017): 937-944.

Rumzhum, N.N., Sohrab, M.H., Al-Mansur, M.A., Rahman, M.S., Hasan, C.M. \& Rashid, M.A. 2012. Secondary metabolites from Jatropha podagrica hook. Journal of Physical Science 23(1): 29-37.

Saluja, R.K., Kumar, V. \& Sham, R. 2016. Stability of biodiesel: A review. Renewable and Sustainable Energy Reviews 62(2016): 866-881.

Shah, S.N., Iha, O.K., Alves, F.C.S.C., Sharma, B.K., Erhan, S.Z. \& Suarez, P.A.Z. 2013. Potential application of Turnip oil (Raphanus sativus L.) for biodiesel production: Physicalchemical properties of neat oil, biofuels and their blends with ultra-low sulphur diesel (ULSD). BioEnergy Research 6(2): 841-850.

Supamathanon, N., Wittayakun, J. \& Prayoonpokarach, S. 2011. Properties of Jatropha seed oil from Northeastern Thailand and its transesterification catalyzed by potassium supported on $\mathrm{NaY}$ zeolite. Journal of Industrial and Engineering Chemistry 17(2): 182-185.

Thapa, S., Indrawan, N. \& Bhoi, P.R. 2018. An overview on fuel properties and prospects of Jatropha biodiesel as fuel for engines. Environmental Technology and Innovation 9(2018): 210-219.

Tsegay, E.Z., Premjet, S., Kongbangkerd, A. \& Premjet, D. 2017. Direct shoot organogenesis from juvenile cotyledon of Jatropha podagrica hook. Asian Journal of Plant Science and Research 7(2): 17-22.

Verma, P. \& Sharma, M.P. 2016. Review of process parameters for biodiesel production from different feedstocks.
Renewable and Sustainable Energy Reviews 62(2016): 1063-1071.

Wang, R., Hanna, M.A., Zhou, W.W., Bhadury, P.S., Chen, Q., Song, B.A. \& Yang, S. 2011. Production and selected fuel properties of biodiesel from promising non-edible oils: Euphorbia lathyris L., Sapium sebiferum L., and Jatropha curcas L. Bioresource Technology 102(2): 1194-1199.

Wu, J., Gao, S., Tang, L., Hou, P., Gao, J. \& Chen, F. 2012. The traits, oil content and correlation studies of seed, kernel in Jatropha curcas L. African Journal of Agricultural Research 7(10): 1487-1491.

Duangporn Premjet

Centre of Excellence in Research for Agricultural Biotechnology Faculty of Agriculture Natural Resources and Environment Naresuan University

Muang Phitsanulok, 65000

Thailand

Abraham Kusi Obeng

Department of Biotechnology

Faculty of Biosciences

University for Development Studies

P.O. Box TL 1882, Tamale

Ghana

Hah Young Yoo

Department of Biotechnology

Sangmyung University

Seoul 03016

Korea

Seung Wook Kim

Department of Chemical and Biological Engineering

Korea University

145, Anam-ro, Seongbuk-gu

Seoul 02841

Korea

Siripong Premjet*

Department of Biology, Faculty of Science

Naresuan University

Muang Phitsanulok, 65000

Thailand

*Corresponding author; email: siripongp@nu.ac.th

Received: 18 July 2019

Accepted: 6 July 2020 